\title{
Degradation Impact of Area Mangrove and Enviromental Management Model in Coastal Surabaya
}

\author{
Ketut Prasetyo \\ \{ketutprasetyo@unesa.ac.id\} \\ Universitas Negeri Surabaya, Indonesia
}

\begin{abstract}
In Indonesia, deforestation of mangrove is highest than the other country. Rate of deforetation in Indonesia 52.000 ha/year or $6 \%$ of ratinal rate. Majority mangrove live in Indonesia is $22 \%$ of in the world, but mangrove is degradation. In coastal Surabaya areal mangrove is change and degradation too. Aim the researched is analysis of causing at mangrove area is degradation, analysis of impact at mangrove area is degradation and analysis enviromental management model in coastal Surabaya. The method of colleeting data is used secundairry data and combination by field obeservation. The model anlysis data is by discribtion analysis. The result of the reseached of causing of mangrove degradation is 1) developt of large is commercial public area, 2) growth of plastic waste in coastal around rivers, and 3) using tree mangrove for burning by people live in around coastal. And the negative impact of mangrove degradation is 1) the incident of sea water intrusion at settlement, and 2) flood at coastall area, speciaist is at coastall West-Surabaya. In Coastal Surabaya,the enviromental management model has by command and control model and education model. But in application in model command and control dissinconizaition with the aftter sources
\end{abstract}

Keywords: degradation, impact, enviromental, management, mangrove.

\section{Introduction}

Derived from the word mangal which shows the community of a plant (Odum 1983). Trees that live in muddy, wet areas (Walsh, 1974). Mangroves usually grow in coastal areas that are river estuaries, with sloping or flat slope, protected from the onslaught of waves and strong tidal currents, temperatures between 20-40 degrees C, and salt water levels between 10-30 per mile.Condition mangrove on the ground reduction.From 1932 mangrove covering in the word 600,000 hectares, but until 2010 few 100,000. hectar This mean exixtensies mangrove degress for 500,000 hectares 


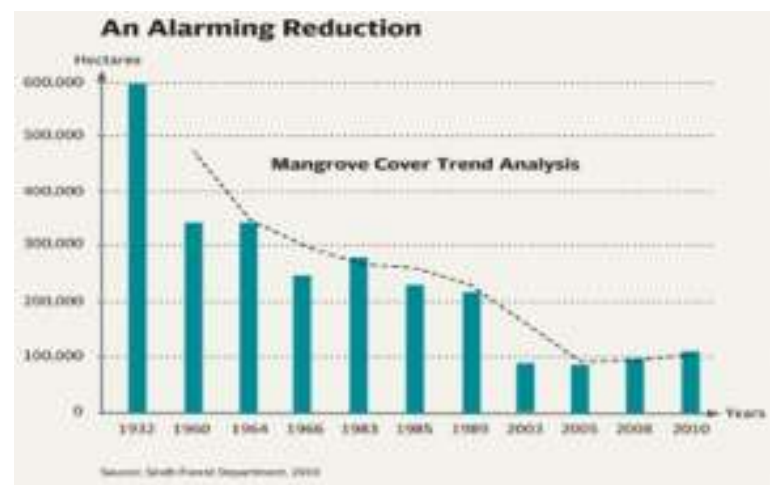

Figure 1. Alarming Reduction of Mangrove

Fothermore, majority mangove live in Indonesia is $22 \%$ of in the world. And the other country is very litle, for examples Brazil-Nigeria-Austria is $6 \%$, Bangladesh-Malaysia is $4 \%$, Cuba-Mexico-India is 3\%, and all other country $40 \%$

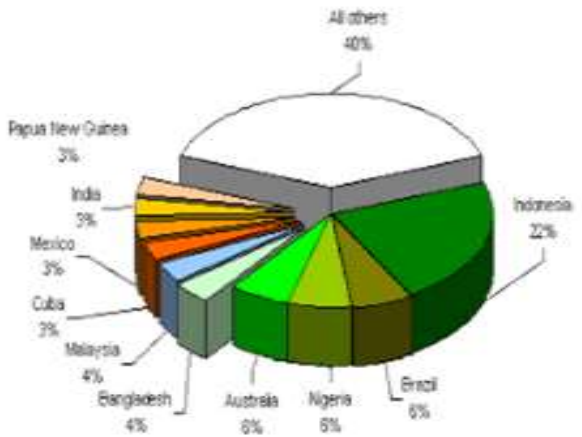

Fifure 2. Distribution Mangrove in the world

In Indonesia, deforestationis of mangrove is highest than the other country.Rate of deforetation in Indonesia 52.000 ha/year or $6 \%$ of natinal rate. Mainly localted in Papua, Kalimantan and Sumatera. About 500 mangrove tree spicies found and dominated by Rhisopora spp. 


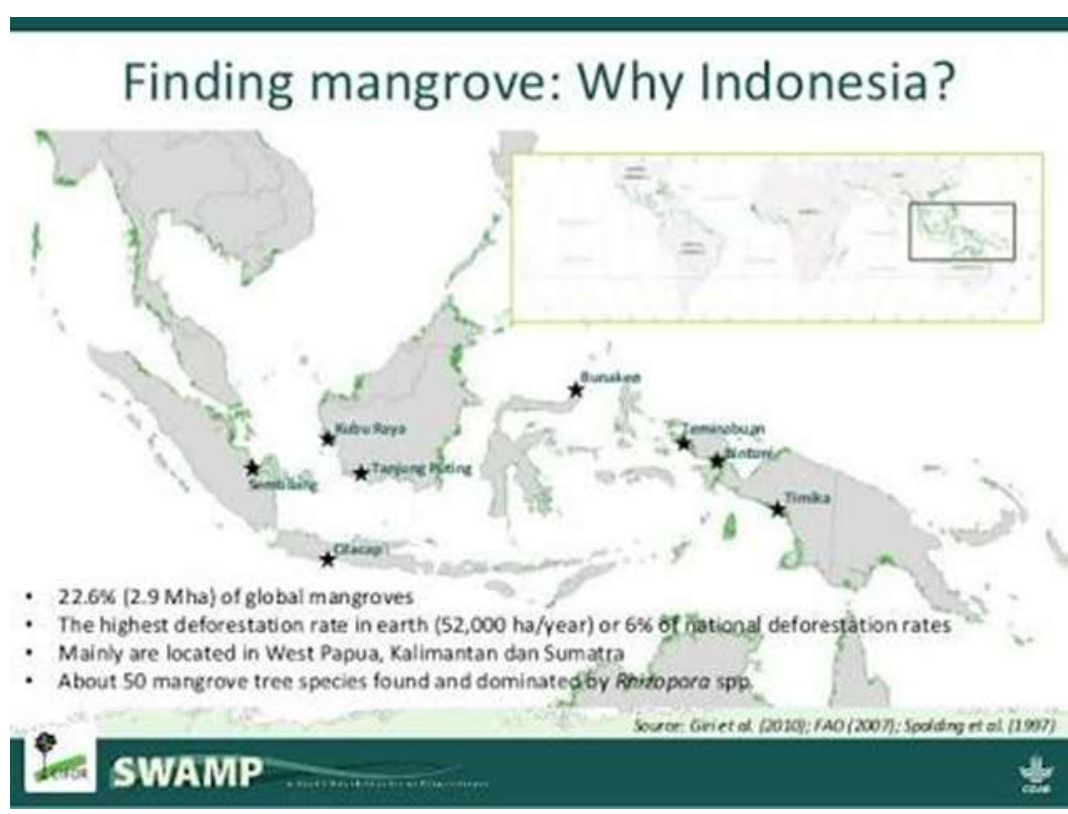

Figure 3. Objective why finding Indonesia

In Java island condition mangrove at last year is very degradation. At 2000 Mangrove is reduction. Condition mangrove at West Java is <8\%, Center Java is 30\%, and East Java $1 \%$ Justice of Urban Planning at Justice of Surabaya Number 12 , years 2014 about Regional Planning and Space of Surabaya tahun 2014-2034 [1]. On this agrrement discribe too regional line of beached and conservation areal of mangrove. Referece from Center Information and Education Mangrove Surabaya at 2011 areal mangove is 471,15 Ha, and degradation areal mangrove is 20,47 ha .

By refer from Viv Djanat Prasita (Procedia Eart and Planetary Science 14, 25-32 2015) Determiination of shoreline chnges from 2002 to 2014 in the mangrove Conservatin Areas of Pamurbaya using GIS, the result showed that shore line in the specified study area have changed, that is $5.387 \mathrm{~m}, 5428 \mathrm{~m}, 5128 \mathrm{~m}$, and $7431 \mathrm{~m}$ in 2002, 2007, 2011 and 2014 respectively.

\section{Aim the Reserached}

Base on tendecies of degradation mangrove in Surabaya, the aim of the reseached is 1. Analysis of causing at mangrove area is degradation in coastal Surabaya

2. Analysis of impact at mangrove area is degradation in coastal Surabaya

\section{Research Method}

Local of the reseached is beached mangrove from Lamong River in West of Surabaya until Rungkut River at Southern Surabaya. Data collection is done by field observations and 
documentation of skundair data related to the purpose of the study. Data collection time is 3 months. Analyze the data used by quantitative descriptive methods.

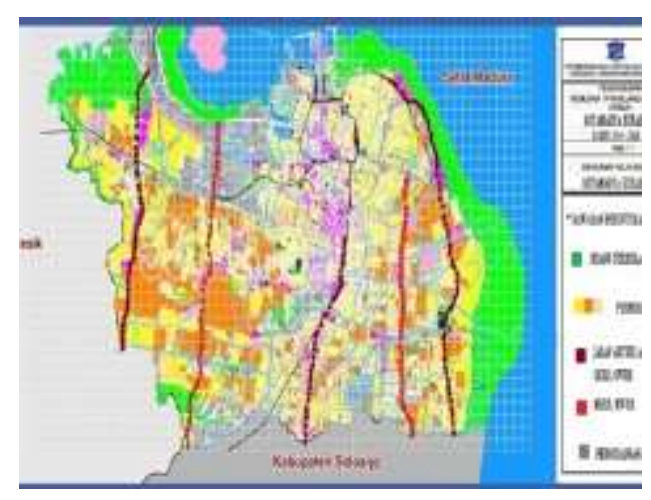

Figure 4. Location of study at Coastal Surabaya

The method of colleting data is by use scundairry data. The form data is map and statistic data. Than, for hight accuracy data the collection is combinationby field obeservation. At the end, after colletion data is finish, than be analisis by discription.

\section{Result and Discussion}

The general description of the Surabya coastal area is as follows. The coastal area of Surabaya during the administration covers 9 sub-districts and 17 sub-districts. The population in the Coastal Zone of Surabaya is approximately 700 thousand people. The lowest population density in Benowo District: 8 people / ha. The highest density is in Semampir Subdistrict 176 people / ha. Land use in the coastal area consists of 38\% housing, $20 \%$ rice fields, $19 \%$ farms, the rest for industry, warehouses, dry fields and so on.

\subsection{Some Causes of Mangrove Degradation at Coastal in Surabaya}

\subsubsection{Development of commercial public areas}

Construction of ports in Teluk Lamong on the West Coast of Surabaya has caused some mangove habitats in the region to experience degradation 

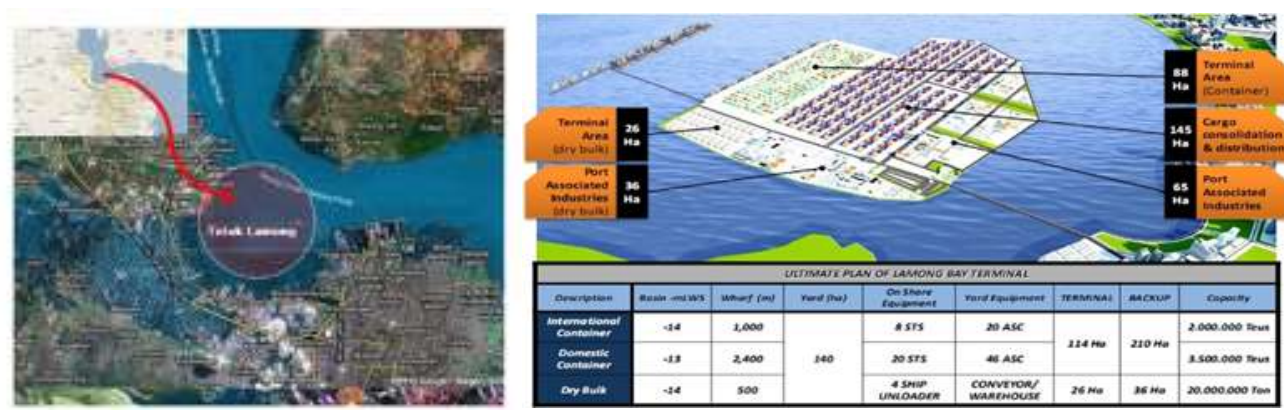

Figure 5. Mangrove area konservation by Port at Lamong Beache

As many as 600 fishermen living in Kenjeran Beach were displaced by elite settlements. In other locations Mangroves in Keputih are damaged due to land clearing for new farms or extraction of mangrove wood (Center for Marine Studies, LPPM ITS, 2012: 16)

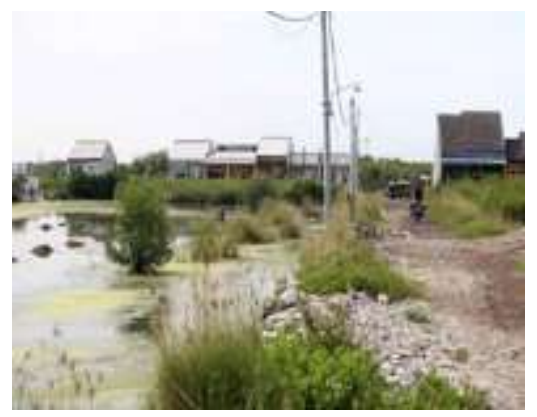

Figure 6. Setlement at area Mangrove Conservation in Medokanayu-Surabaya

\subsubsection{Increased plastic waste in the river mouth where mangroves grow}

Some estuaries that flow on the coast of Surabaya have accumulated plastic waste. The presence of plastic waste in the river mouth and in the mangrove area threatens the existence of mangroves.

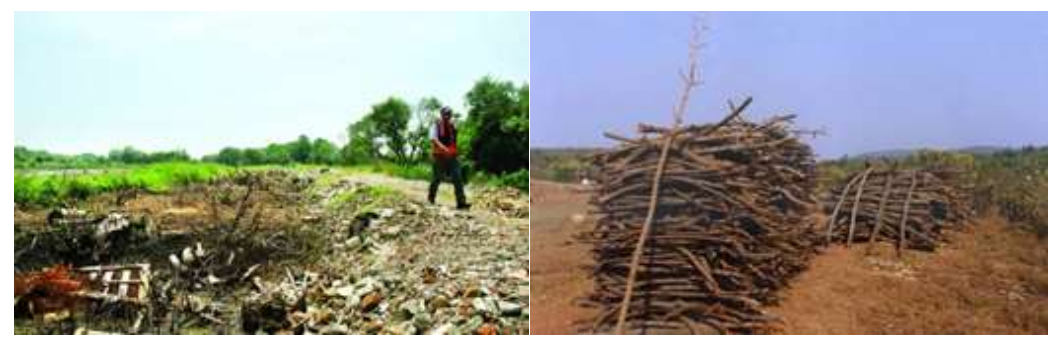

Figure 8. Mangrove at Gunung Anyar and Medokanayu For burning oak 


\subsection{Negative Impact of Mangrove Degradation at Coastal Surabaya}

\subsubsection{Occurrence of Sea Water Intrusion}

One of the consequences of the degradation of mangroves on the coast of Surabaya has caused sea water intrusion in several locations with various categories of intrusion. According to Research Anis Ariyanti (2015) [2] it is known that in the coastal area of Surabaya sea water intrusion has occurred with the following conditions: Mild intrusion occurred in Gung Anyar District 1 well, Rungkut District 3 wells, Sukolilo District 4 wells, Tambaksari District 5 wells, District Mulyorejo 2 wells and Gubeng District 2 wells. Intrusion is taking place in Gunung Anyar sub-district 5 wells, Rungkut sub-district 2 wells and Mulyorejo sub-district 6 wells [2].

\subsection{Flooding}

Floods can occur because of overflowing river water or flooding due to rising sea levels. Floods due to overflow of river water which empties into the coast occur because of changes in the function of land use that used to be mangrove forests and then changed for other uses. Floods in Lamong City and West Surabaya Beach were analyzed because the change in mangrove coastal swamps has been reclaimed as a port.

\subsection{Analysis of the Application of Environmental Management Models in Surabaya Coastal Areas.}

Taking into account the causes and consequences of mangrove degradation in the Coastal Zone of Surabaya is very interesting to discuss about exploring the mangrove environment management model in the Surabaya Coastal Area.

\subsubsection{Application of the Law Enforcement Model}

The management model for enforcing rules or regulating and supervising models has been applied in the Surabaya Coastal area. This is evidenced by the existence of Regional Regulations concerning the Surabaya City Regional Spatial Planning and City Region No.12 of 2014 concerning the Surabaya City Spatial and Regional Plan 2014-2034. However, if we refer to Law Number 27 of 2007 concerning Management of Coastal Areas and Small Islands, Article 1 paragraph one (Sea areas relating to land covering 12 miles from the coastline are conservation areas, then there has been a mismatch in administrative planning) [3]. space in the Surabaya Coastal Area Some facts in the field of settlements that are built as a result of mangrove forest conservation are proof of the lack of synchronization of environmental management through the enforcement of regulations or legislation.

\subsubsection{Application of Educational Models}

In managing the environment to overcome the Mangrove degeneration in Pantai Surabaya an educational model has been applied. It can be seen that the Mangrove Tourism Area in Wonorejo is made which functions in addition to tourism and is also used for education and conservation 


\section{Conclusion}

Based on the results of the study it can be concluded the following matters

1 Due to the degradation of mangrove on the coast of Surabaya due to the development of public areas that change the function of land in the mangrove area, the increase of plastic waste in the river mouth where mangroves grow, and the use of mangroves by the population for firewood.

2 As a result of the degradation of mangroves on the coast of Surabaya it is known that sea water intrusion and flooding have occurred in the coastal areas of Surabaya.

3 In an effort to manage the presence of mangroves in the coastal area of Surabaya it is known that there is a model of law enforcement management and a management model using an educational approach.

\section{References}

[1] Perda Kota Surabaya No.12 Tahun 2014 Tentang Rencanata Tata Ruang Dan Wilayah Kota Surabaya Tahun 2014-2034. .

[2] A. ARIYANTI, "PEMETAAN INDIKASI INTRUSI AIR LAUT DI DAERAH SURABAYA TIMUR BERBASIS SISTEM INFORMASI GEOGRAFIS (SIG).” UNIVERSITAS AIRLANGGA, 2015.

[3] Uu No 27 Tahun 2007 Tentang Pengelolaan Wilayah Pesisir Dan Pulau-Pulau Kecil. .

Bharatdwaj. 2009. Introduction Physical Geography. New Delhi: Discovering Publishingh House Pvt, Ltd

Colin Marsh. 2005. Studies Of Society And Enviroment. Australia: Pearson Prentice Hall. 